The Catholic University of America, Columbus School of Law

CUA Law Scholarship Repository

1978

\title{
Pro Peccatis Patrum Puniri: A Moral and Legal Problem of the Inquisition
}

Kenneth Pennington

The Catholic University of America, Columbus School of Law

Follow this and additional works at: https://scholarship.law.edu/scholar

Part of the History of Christianity Commons, and the Religion Law Commons

\section{Recommended Citation}

Kenneth Pennington, Pro Peccatis Patrum Puniri: A Moral and Legal Problem of the Inquisition, 47 CHURCH HIST. 137 (1978).

This Article is brought to you for free and open access by the Faculty Scholarship at CUA Law Scholarship Repository. It has been accepted for inclusion in Scholarly Articles and Other Contributions by an authorized administrator of CUA Law Scholarship Repository. For more information, please contact edinger@law.edu. 


\section{"Pro Peccatis Patrum Puniri": A Moral and Legal Problem of the Inquisition}

\section{Kenneth Pennington}

The first letter in Pope Innocent III's register of his second year was Vergentis in senium, a letter which he sent to the city of Viterbo in March, 1199. The decretal reflected Innocent's growing concern with heresy in the papal states and established new and more stringent penalties for those who rejected or subverted the Christian faith. In Vergentis, perhaps following the Roman lawyer Placentinus, Innocent imposed the traditional spiritual punishment of excommunication on heretics, equated heresy with lese majesty, and applied to convicted heretics the sanctions for treason in Roman law: complete confiscation of goods, even disinheriting innocent children. ${ }^{1}$ The punishment was fitting, Innocent observed, because a heretic injured celestial majesty, a crime far more heinous than any offense committed against temporal authority. Since the heretics in Viterbo continued to demand his attention later in his pontificate, we do not know how effective Innocent's decree was, but Vergentis did establish a precedent for papal action throughout Christendom. In order to root out all vestiges of heresy, Innocent extended the provisions of the decretal from the heretics themselves to their "supporters, defenders, and harborers." The decretal marked the first firm step of his increasingly grim policy to use all of the resources of the church to extirpate heresy from Christian lands. The step from Viterbo to the Albigensian crusade was a short one. And, since heresy was an ecclesiastical crime, both laymen and clerics who were accused of heresy had their cases heard in ecclesiastical courts, giving lawyers another item to add to the list of cases in which the pope could exercise jurisdiction in the secular world. Until the persecution of heresy fell into desuetude in the eighteenth century, the law of heresy was governed by the stark provisions of Vergentis. The inquisition's modern chronicler, Henry Charles Lea, remarked that "if there were those [in the fifteenth and sixteenth

1. The major studies of Vergentis have been by Henri Maisonneuve, Études sur les origines de l'inquisition, 2nd ed. (Paris, 1960), pp. 156-157; 281-284; 339-357. W. Ullmann, "The Significance of Innocent III's Decretal Vergentis," Études d'histoire du droit dediees à Gabriel Le Bras (Paris, 1965), 2.729-743. O. Hageneder, "Studien zur Dekretale 'Vergentis' (X V.7.10). Ein Beitrag zur Häretikergesetzgebung Innocenz III.” Zeitschrift der Savigny-Stiftung für Rechtsgeschichte, Kan. Abt. 49 (1963), pp. 138-173. Of the older studies, H. C. Lea, History of the Inquisition (New York, 1906) 1:501-503 is detailed and informative.

Mr. Pennington is professor in the Department of History, Syracuse University, Syracuse, New York. 
centuries] who questioned the justice of punishing the orthodox children for their parents' heresy, they were triumphantly silenced by Alfonso de Castro."2 Castro, the sixteenth-century Spanish inquisitor, had written a tract which defended the inquisition and the church's right to punish the children of heretics. The story, however, is not so neat or simple. Lawyers struggled with the legal and moral problems raised by Innocent's legislation for five centuries, and their solutions reflect changing attitudes toward law and its function in society and toward heresy as a threat to Christian society.

Vergentis can be viewed as a logical development from earlier legislation - the confiscation of goods for heresy was a policy developed during the late Roman empire and continued until the twelfth century - but the harsh provisions of the law were quickly seen as an important change in the laws governing heresy, and the canonists soon included the decretal in their collections. Rainer of Pomposa in 1201, Gilbertus in 1202/03, Alanus in 1206, and Bernardus Compostellanus in 1208 added the decretal to their collections, and in 1209/10 Petrus Beneventanus followed his predecessors and put Vergentis in Compilatio tertia under the title de hereticis (3 Comp. 5.4.1). In 1234 Raymond de Pennafort placed the decretal in the Decretals of Gregory IX, giving Vergentis (10 5.7.10) a permanent position in ecclesiastical law. ${ }^{3}$

The canonists accepted excommunication, infamy and the confiscation of goods as just punishments for heresy, and, surprisingly, were not disturbed that Innocent lumped the defenders and supporters of heretics indiscriminately with the heretics themselves. Innocent modified his opinion in subsequent legislation and changed the penalty for the supporters and receivers of heretics sixteen years later at the Fourth Lateran Council. In the canon Excommunicamus, he ordered that those who gave aid to heretics should be excommunicated and, after one year, be rendered infames (i.e. not allowed to hold public office, receive inheritances etc.). He did not mention their sons. ${ }^{4}$ Hageneder probably hypothesizes correctly that Innocent changed his mind because of

2. A History of the Inquisitıon of Spain (New York, 1966) 3:173. For further information about the lawyers mentioned in this paper see J. F. von Schulte, Die Geschichte der Quellen and Literatur des canonischen Rechts (3 vols.; Stuttgart, 1875-1877). S. Kuttner, Repertorium der Kanonistik (1140-1234) (Città del Vaticano, 1937).

3. Hageneder, "Vergentis," pp. 149-150. On the "official" character of Compilatio tertia, see "The French Recension of Compilatio tertia," Bulletin of Medieval Canon Law 5 (1975):64-67. In another essay which will appear in The Proceedings of the Fifth International Congress of Medieval Canon Law, Salamanca, I argue that Innocent III did not order the compilation of 3 Comp., but instead authenticated or approved the collection.

4. 4th Lat. c.3 [4 Comp. 5.5.2(X 5.7.13)]. For the text of Excommunicamus, see Concllorum decumenicorum decreta, ed. J. Alberigo et al. (3rd ed. Bologna, 1973), 233-235. In referring to legal texts, I shall use the following abbreviations: $\mathrm{X}=$ Decretals of Gregory IX; Comp. = Compilatio antiqua (prima-quinta). These works can be conveniently found in editions by E. Friedberg (Leipzig 1879) and (Leipzig 1882). 
political difficulties which he encountered when the church enforced the provisions of Vergentis, for the lawyers who wrote before the Fourth Lateran did not object to the rigorous punishment of defenders or receivers of heretics, and the early canonists showed little inclination to ameliorate the provisions of Vergentis. Of the canonists who touched on the problem, Johannes Galensis (c. 1210) noted that one could, in law, often be punished for the crime of another and implied that Vergentis was not too harsh. ${ }^{5}$ Laurentius Hispanus $(c .1210)$ proposed that a relative who protected a heretic should be punished as severely as others who were not bound by ties of blood. Roman law supported the notion that a relative who harbored or abetted a criminal should receive a lesser sentence, but Laurentius concluded that a distinction between relatives and non-relatives should not be made in the case of heresy. ${ }^{6}$ Although subsequent papal legislation was not affected by canonistic opinion, when Raymond de Pennafort placed Vergentis in the Decretals of Gregory IX, he made a slight change in the wording of the text which brought the decree into congruence with Excommunicamus. ${ }^{7}$

The other major provision of Vergentis stipulated that the orthodox sons of heretics be left destitute and prevented from inheriting any part of their father's estate. Since Innocent considered heresy as a treason against God, there is some logic to his conclusion that the penalties for heresy should be the same as those for treason in Roman law. Roman law had not equated treason and heresy. In Roman law, the sons of a heretic could inherit part of their father's possessions, and if the heretic had no sons, the orthodox relatives became the legitimate heirs. ${ }^{8}$ However, traitors to the emperor suffered complete confiscation of their goods. ${ }^{9}$

5. Johannes Galensis to 3 Comp. 5.4.1(X 5.7.10), v. credentibus confundatur: "Non, quod sepe punitur unus altero, ut ii. q.vii. Qualis, Sententia (C.2 q.7 c.9 and c.12)" (Munich, Staatsbibl. 3879, fol. 250v).

6. Laurentius Hispanus to 3 Comp. 5.4 .1 v. receptoribus: "Sine quibus heretici diu manere non possunt, et ideo merito puniuntur, arg. ff. de offit. presid. Congruit (Dig. 1.18.13) et ff. de recept. 1.i. (Dig. 4.8.1) nisi forte proximos recipiant, puta agnatos (MS “agrares”), tunc enim non ita grauiter punientur, arg. ff. de recept. 1. finali (Dig. 4.8.52). Quod non concedo hoc (MS "hic") casu, arg. supra xxvii q.i. De filia (C.27 q.1 c.26). Puniuntur autem (MS "an") eadem pena receptatores (MS "receptationis") et isti, arg. C. de his qui latron. occult. 1.i. (Cod. 9.39.1)." (Karlsruhe Aug. XL, fol. 215r). Hageneder, "Vergentis," p. 145, fn. 24.

7. Hageneder, "Vergentis," p. 149. The seventeenth-century lawyer, Emanuel Gonzalez Tellez of the University of Salamanca, noted in his commentary to Vergentis that Raymond had changed the wording of Innocent's decree. With the change, confiscation did not apply to the supporter and defenders of heretics. He hypothesized that since neither Innocent's decretal in the Fourth Lateran Council, Excommunicamus, nor Frederick II's legislation of 1220 demanded confiscation, "forsan ... haec poena confiscationis bonorum usu recepta non fuit." Commentaria perpetua (Lyon, 1715), 2.179.

8. Cod. 1.5.19 (Cognovimus). Maisonneuve, L'inquisition, pp. 29-32. On the general problem of punishing the innocent, see V. Piergiovanni, La puniblità degli innocenti nel diritto canonico dell' età classica, 2 vols. (Milan, 1971-1974).

9. The Emperors Honorius and Arcadius promulgated Quisquis (Cod. 9.8.5) in 397. 
The first canonist to comment on Vergentis was Alanus (c. 1206) who wrote a gloss to the decretal for his own collection. He included the decretal, he said, as much for the language of the decree as for the decision itself, because (quoting Horace, Ars poetica, 343) he who mixes the useful with the sweet receives praise. ${ }^{10}$ Innocent's regal language impressed Alanus, and perhaps the pope had a hand in drafting Vergentis for the images in the letter are similar to those found in his sermons. ${ }^{11}$

Shortly after Alanus, Johannes Galensis (c. 1210) wrote an extended commentary upon Vergentis. He noted that the pope could make a person infamis in the secular forum despite Gratian's contrary opinion and that heresy was another case in which the pope could exercise secular jurisdiction obentu peccati. ${ }^{12}$ Although Laurentius (c. 1212) thought that Innocent "seemed" to emend Roman law with the decretal, ${ }^{13}$ Johannes Teutonicus (c. 1217) was the earliest canonist to state explicitly that Vergentis corrected Roman law and substituted harsher sanctions against heresy. Heresy, he said, was one of three ecclesiastical crimes in which sons were excluded from hereditary succession. The other two were simony and the murder of clerics. ${ }^{14}$

None of the early canonists questioned the right of the pope to increase the penalties for heresy. The only unusual gloss appears in an anonymous commentary (c. 1215) once attributed to Laurentius, but now known by its incipit, Servus appelletur. ${ }^{15}$ In a comment to the words

10. Alanus Anglicus, in a gloss to his own collection (W. and A. 5.6.1): "Potius quam uerbis quam pro sententia est hoc capitulum insertum quoniam contulit punctum qui miscuit utile dulci" (Vercelli 89, fol. 116v). This was Alanus' only gloss to the decretal. On the Vercelli MS see S. Kuttner, "The Collection of Alanus: A Concordance of its Two Recensions," Rivista di storia del diritto, 26 (1953): 37-53.

11. The images and scriptural passages used to describe heresy were well established by the early thirteenth century, and similarities of style or of images in Innocent's writings would not prove that he drafted Vergents. I note only that the beginning sentences of Vergentes and two of his sermons contain exactly the same images. See Sermon 12, (J.-P. Migne, Patrologia . . Series Latina $[P L] 217: 647$ ) and Sermon 2, PL 217.655.

12. Johannes Galensis to 3 Comp. 5.4.1 v. consilıa ciuntatum: "Nota papa quantum ad forum ciuile posse infamiam infligere, sed cur non absoluere infamatum, ut supra ii. q.iii. Hinc colligitur? (C.2 q.3 d.p.c.7). Solutio. Immo potest et quod ibi dicit Gratianus non est uerum." v. precipimus fieri: "Quod facere potest papa obtentu peccati, supra de iud. Nouit, lib. eodem" (Munich, Staatsbibl. 3879, fol. 250v).

13. Laurentius Hispanus to 3 Comp. 5.4 .1 v. exheredato filiorum: "Videntur ergo ex hoc recipere correctionem iura que dicunt bona hereticorum deuoluenda ad filios fideles, ut C. eodem titulo Manycheos, uel si non habent filios fideles, ad cognatos uel angnatos fideles, ut C. eodem titulo Cognouimus (Cod. 1.5.19) et authentico ibi posito Idem de Nestorianis (Nov. 1 15.3.14)" Karlsruhe Aug. XL, fol. 215v).

14. Johannes Teutonicus to 3 Comp. 5.4.1 v. filiorum: "Sic patet quod secundum canones bona hereticorum confiscantur, siue habeant filios siue non, et in hoc corrigitur lex que dicit quod bona eorum ad cognatos uel agnatos deferuntur. .. Nota quod in tribus criminibus fili excludentur, scilicet in crimine heresis et symonie, ut hic et vi. q. 1 $\S$ Verum (C.6 q.1 d.p.c.21), et in interfectore clericorum" (Admont 22, fol. 231v). Not Johannes Galensis: Maisonneuve, L'inquisiton, p. 281.

15. On which see K. Nörr, "Der Apparat des Laurentius zur Compilatio III." Traditio 17 (1961): 542-543. 
"orthodox sons," the anonymous lawyer wondered whether the pope did not become "iudex suus"-an interested party to the case-because he punished his own adversaries. Although the glossator only raised the question and did not provide an answer, he seemed to consider heretics rivals of the papacy in the fight for men's souls. He probably had the well-organized sects of central Italy in mind since they seemed a formidable foe for the papacy, but his unusual gloss did not engage the interest of later lawyers. ${ }^{16}$

Tancred (c. 1220), the ordinary glossator of Compilatio tertia, broke the canonists' pattern of passive reception of the decretal almost twenty years after it had been issued. Although he agreed with prior opinion which held that the pope could prosecute heretics ratione peccati, he was disturbed by the severity of Innocent's decision, and his concern centered on the treatment of orthodox sons. Tancred noted that Innocent had sent the decretal to Viterbo, a city in the papal states, and concluded that the law was valid only in the patrimony of St. Peter. "In other lands, the (Roman) laws prevail because they are supported by greater equity, and equity should always be preferred to strict law."17

By the time in which Tancred wrote, the strictures of Vergentis had been incorporated into papal decretals which had been sent to many parts of Europe. Tancred's gloss was not, however, an arbitrary display of academic myopia concerning the current legal situation. Even though the canonists often said that "no gloss can injure or change the law,"18

16. 3 Comp. 5.4.1 v. orthodoxorum: "Econtra C. de heret. et man. 1. Cognouimus (Cod. 1.5.19), authen. Idem de Nestorianis (Nov. 115.3.14), set dic quod ecclesia possit, quia magis ab eis leditur, magis eos prosequitur. Set nonne papa in hoc casu est iudex suus ubi aduersarios suos auctoritate sua punit, simile supra de translat. epis. Inter corporalia (3 Comp. 1.5.2 = X 1.7.2) et ii. q.vii Si quis erga (C.2. q.7. c. 16)" (Bamberg Can. 19 , fol. 208v). This gloss is garbled in Paris Bibliotheque Nationale 3932, fol. $188 \mathrm{r}$.

17. Tancred to 3 Comp. 5.4.1, v. exheradatio filiorum: "Expresse dicitur hic quod bona hereticorum confiscantur siue filios habeant siue non, nec catholicis filiis hereticorum est aliquid relinquedum, sed contra dicunt leges, C. de heret. Manicheos (Cod. 1.5.4) et l. Cognouimus (Cod. 1.5.19) et authen. Idem est de Nestorianis, (Nov. 115.3.14) ubi dicitur quod bona hereticorum deuoluuntur ad filios orthodoxos; si <non $>$ habent, deuoluuntur ad cognatos uel catholicos. Ad hoc dixerunt la. et jo. quod hec decretalis corrigit leges illas, et ius illud antiquum traitur ad istud nouum, arg. ff. de legibus et constit. Non est nouum (Dig. 1.3.26) et supra de cognat. spirit. c.i. lib. i. (1 Comp. 4.11.1 = X 4.11.1) Ego dico hanc decretalem preualere legibus supradictis in terris illis dumtaxat que subsunt temporali iurisdictioni domini pape, sicut ex littera precedenti probatur. In aliis autem terris preualent leges predicte que maiori equitate nituntur. Hec decretalis de seueritate loquitur ut ex littera patet. Equitas enim iuri stricto preferenda est, ut C. de iudic. Placuit (Cod. 3.1.8), nam cum hec sit pena molienda est et non exasperanda, ut supra de pen. di.i. § Pene (De pen. D.1.c.18).t." (Vat. lat. 1377, fol. 264v).

18. For just one example of this aspect of canonistic thought which they often cheerfully ignored, see the Ordinary Gloss to X. 2.26.14, v. centum annorum. Innocent III had decreed that only a one-hundred year prescription was valid against the Roman church. Johannes Teutonicus had found this absurd, for he did not think a one-hundred year prescription could be proven. Therefore, he used the test of "what reaches beyond the memory of man" to prove such a prescription. Bernardus Parmensis quoted Johannes' 
the writings of the canonists were often important sources of law throughout the Middle Ages. They argued points of law in the classroom and in their commentaries, and the product of this dialectic was often a consensus of how a particular decretal should be interpreted. Sometimes their consensus changed the law as it was expounded in the courts. There are numerous examples of this practice in the writings of the jurists, and their skill at reshaping old law to new situations may be partially responsible for the absence of new codes of canon law in the later Middle Ages. ${ }^{19}$ Tancred modified Vergentis not only by limiting its effect to the papal states, but also by arguing that papal law should not be universal throughout Christendom when greater equity could be found in Roman law. Although the legislative authority of the Roman church might seem to be questioned in Tancred's gloss he was a staunch advocate of papal power. He did not invoke the Germanic notion that old law is the best law, for he was well aware that the pope could annul old law. The gloss instead reflects a thirteenth-century notion that law possessed an intellectual and logical life apart from questions of legislative authority, juridical jurisdiction, or historical development. When the canonists wished to obviate a portion of papal legislation, they rarely asserted that the pope did not have the power or the right to make such a law. Instead, their route was more tortuous. Either they interpreted the law so that the unwanted provisions were eliminated, or they found general legal principles which the pope had unwittingly violated.$^{20}$ If, as in the case of Vergentis, a papal decretal offended equity, the canonists' interpretation did not impugn the authority of the church or her ruler.

Tancred's doubts about the equity of Vergentis stimulated a long discussion in the literature which lasted until the seventeenth century. Jacobus de Albenga (c. 1230) and Zoen Tencararius (c. 1230) wrote commentaries on Frederick II's legislation of 1220 which Tancred himself had included in Compilatio quinta. Frederick had issued the substance of Vergentis as a part of imperial legislation, but neither Jacobus nor Zoen objected to disinheriting the sons of heretics. Jacobus pointed out that Frederick's decree, issued to all who live under his imperium, reproved Tancred's opinion. ${ }^{21}$ Shortly afterwards, Vincentius Hispanus $(c .1240)$

gloss, but concluded: "Sed non recedendum est a uerbis istis . . . et sufficit quod ita placuit legislatri."

19. See J. Brundage's interesting remarks in "The Creative Canonist: His role in Church Reform," The Jurnt 31 (1971): 301-318. Brundage discusses several cases in which the canonists either changed, altered or limited papal legislation.

20. For a specific example, $s \rightarrow$ Pennington, "The Canonists and Pluralism in the Thirteenth Century," Speculum 51 (1976): 35-48.

21. Zoen to 5 Comp. 5.4.1 (X ---), v. non possint: "Est enim unus casus in quo filius caret successione paterna per delictum patris; alius in crimine lese maiestatis, ut $\mathrm{C}$. ad leg. Iul. mai. Quisquis (Cod. 9.8.5), quam legem habes vi. q.i § Vestrum (recte Verum), uer. Si quis cum mulieri (recte militibus) (C.6 1.1 d.p. c.2 1)" (Tours, Bibl. mun. 565, fol. 37r). 
copied Tancred's gloss and placed it in his own commentary to the Gregoriana, but he thought Tancred had blundered. At the end of the gloss, he wrote "I, Vincentius, adhere to this decretal and those which are similar; he was a Lombard who wrote the preceding gloss." ${ }^{22}$ Vincentius' opinions were often trenchant and acerbic, and he did not hesitate to castigate the mistaken opinions of other lawyers; the origins of such fuzzy thinking, he thought, could often be found in a man's nationality. ${ }^{23}$

At almost the same time Vincentius wrote, Goffredus de Trani endorsed Tancred's opinion and expanded upon the church's obligation to render justice to Christians. Like Tancred, he limited the effect of Vergentis to the papal states; in other parts of Europe, the more equitable provisions of Roman law should prevail. He went on to argue that when the church had certain knowledge that the sons of heretics were orthodox, faithful, and devoted Christians, these sons should not be punished. The implication of Goffredus' gloss is that orthodox sons should not be punished even within the papal states, for he had already exempted those who lived outside of the patrimony from the provisions of Vergentis. The church, said Goffredus, should love and help all men, and no one should be excluded from the flock. He then tempered his position by giving the texts of Roman law which Innocent may have thought were applicable to heresy. "The Church often punishes sons temporally for the sins of their fathers," he concluded. ${ }^{24}$ Later canonists

Jacobus to 5 Comp. 5.4.1 (X ---) v. filii ad successionem: "Siue fuerint heretici siue ortodoxi ut supra eodem Vergentis, circa finem, et ita per hanc legem et per illam decretalem, Vergentis ( 3 Comp. 5.4.1 = X 5.7.10), corriguntur antiqua iura bona hereticorum reseruabunt filiis ortodoxis, ut C. eodem Manicheos, Cognouimus (Cod. 1.5.4 and 1.5.19), et authen. Idem de Nestorianis (Nov. 115.3.14) et i. q.iii.Iudei (C.1 q.4 c.7), reprobata opinione t. quam recitauit super illa decretali, Vergentis, in fine. jac." (Cordoba, Bibliotheca del Cabildo 10, fol. 335r). Since he included Frederick's legislation in 5 Comp., Tancred may have changed his mind about Vergentis in the time since he had written his commentary to 3 Comp.

22. Vincentius to X.5.7.10, v. filiorum: "Ego Vincentius sto illi decretali et similibus, et qui precedentem glosam fecit, Lonbardus fuit. uinc.” (Paris, B.N. 3967, fol. 184v). Maisonneuve failed to notice this tag on the end of Tancred's gloss in Vincentius' commentary. Consequently, he thought Vincentius agreed with Tancred, but wondered which canonist formulated the opinion first. L'inquisition, pp. 281-283.

23. See Vincentius' comments on Alanus and Tancred quoted by J. F. von Schulte, Die Geschichte der Quellen, 1:192.

24. Goffredus to $X 5.7 .10$, v. seuertatis: "Vere seueritas est. Leges enim que dicunt puniendos filios ledentium imperialem maiestatem timuerunt ne filii talium essent imitatores paterne iniquitatis, ut vi. q.i. Verum. C. ad leg. Iul. mai. Quisquis, sed si ecclesia uideat per certa indicia fidem et deuotionem filiorum hereticorum, quomodo puniet eos cum pena suos debeat actores tenere, ut supra de hiis que fiunt a maiori par. cap. Quesiuit (2 Comp. 3.9.2=X 3.11.2), cum filius non debeat puniri pro patre, ut C. ne filius pro patre (Cod. 4.13), cum ecclesia debeat omnes iuuare, omnes amare, ut viii. q.i. Clemens (C.8 q.1 c.13), nulli claudere gremium, ut C. de sac. sanc. eccles 1 . ult. (Cod. 1.2.25(26)) Forte Innocentius sumpsit hanc seueritatem ex lege, C. eodem titulo 1. Manicheos (Cod. 1.5.4), et in pena filiorum considerauit penam parentum, ut $\mathrm{ff}$. 
thought that Goffredus had favored Tancred's opinion, even though he had just presented both sides of the issue and had not given a definitive solution to the question.

By the middle of the thirteenth century, then, the canonists had developed two distinct schools of thought on Vergentis. One attempted to limit the provisions of the decretal; the other found the crime of heresy so serious that any measure which eliminated heresy or heretics was justified. Bernardus Parmensis (c. 1250), the author of the Ordinary Gloss of the Decretals of Gregory IX, was persuaded by the second position, and he looked back to Johannes Teutonicus and Vincentius in his exposition of Vergentis. ${ }^{25}$

Although the Ordinary Gloss was important, its authority was not absolute. The most sophisticated canonist of the thirteenth century, Hostiensis $c .1250$ (Henricus de Segusio), was less hostile to Tancred's opinion and tried to harmonize the two lines of thought. He reasoned that both positions could be justified by making a distinction between a heretic who died before his heresy was discovered and one who was condemned during his lifetime. Only the children of the former could inherit his possessions. Or, Hostiensis concluded, one could mete out the milder penalty of Roman law even in the second case, but the rigor of the law was then tempered by mercy, not by any legal right of the defendant. ${ }^{26}$ At the end of the thirteenth century, though, Guido de Baysio (c. 1300) reviewed earlier canonistic opinion when he wrote his Rosarium on the Decretum and concluded that Johannes Teutonicus and his followers had the better argument. The sons of heretics must be punished according to the rigor of the law. Further, if one examined the decretal Vergentis, said Guido, the wording of the letter included the lands of the Roman church as well as other lands. ${ }^{27}$ Both Hostiensis and

quod metus causa 1. Isti quidem (Dig. 4.2.8). Frequenter enim ecclesia punit temporaliter filium pro delicto patris, ut xv. q.vi Cum multe (C.15 q.8 c.3), i. q.iiii. § Item peccato (C.1 q.4 d.p.c.11), i. q.i. Cito (C.1 q.1 c.16), supra de fil. presbyt. per totum. g." (Paris, B.N. 15402, fol. 156v). He repeated this gloss in his Summa (Lyon, 1519), fol. $207 \mathrm{v}$.

25. Bernardus Parmensis to X 5.7.10, v. exhaeredatio.

26. Hostiensis, Summa aurea (Venice 1574) 1536. "Veruntamen et prima sententia saluari potest, quia sententia Azonis et leges sue, idest pro eo inductae, intelligi possunt quando hereticus mortuus est ante accusationem et denunciationem, cum occultus esset, sententia uero Placentini locum habet post accusationem et publicationem, secundum ea que not. supra ... uel dic quod etiam post sententiam latam potest intelligi uera lex et sententia Azonis: sed intelligitur loqui de misericordia, non de rigore." In his commentary to Vergentis, Hostiensis referred to the solution in his Summa aurea as being his final thoughts on the matter. Azo's and Placentinus' opinions are discussed by Maisonneuve, L'inquisition, pp. 63-64.

27. Guido de Baysio, Rosarnum (Strassburg, 1473), unfoliated, to C.23 q.7: "Sed quicquid dicatur si bene ponderetur litera illius decretalis Vergentis $\S$ Nec huius, inuenitur quod illa litera loquitur tam in terris romane ecclesie quam aliorum, et hoc denotatur cum dicit huius seueritatis cum de omnibus illis terris ibi litera premittatur, et sic remanebit illa generalis et predicta decretalis Excommunicamus, et ita dictum Joannis et sequacium firmum erit ut hoc dicit." 
Guido exercised considerable influence on later canonistic thought, and their disagreement insured discord among the lawyers.

Secular rulers combated heresy as actively as the papacy. Frederick II not only incorporated the penalties of Vergentis in his legislation for imperial lands in 1220 (which legislation, as we have seen, became a part of Compilatio quinta) but also issued a large number of complementary decrees which attacked the curse of heresy, for this was one issue upon which the papacy and Frederick agreed. Frederick's legislation appeared in his codification for Sicily, the Liber Augustalis of 1231, and in 1238, Pope Innocent IV had three of Frederick's laws sent out as part of papal letters to several Italian cities. ${ }^{28}$

Although his decrees of 1220 were in full concord with canon law, Frederick's mature legislation stiffened the sanctions against heretics considerably. An especially draconian feature of his legislation allowed the sons of heretics or the sons of their supporters to claim their inheritance if they gave evidence against their fathers; the measure was, however, short-lived and did not survive the thirteenth century. ${ }^{29} \mathrm{We}$ must not imagine that the proliferation of legislation created an accepted penalty or even made known the treatment of heretics. Maisonneuve cites a striking example of how slowly law could spread in medieval Europe. In 1231, a decree issued at Worms ignored both the secular and the ecclesiastical law of heresy, stating simply that the faithful sons of heretics should not be deprived of their inheritance. ${ }^{30}$ Then as now, legal practice and theory of law could be quite different.

The most important law in the Liber Augustalis for our study was Patarenorum receptatores (L.A. 1.2) ${ }^{31}$

Patarenorum receptatores, credentes et complices et quocumque modo fautores, qui ut a poena possint alios eximere, de se velut improvidi non formidant, publicatis bonis omnibus relegandos in perpetuum esse censemus. Et ipsorum filii ad honores aliquos nullatenus sumantur, sed infamiae perpetuae nota laborent, ut nec in testes nec in causis quibus repelluntur infames, aliquatenus admittantur. Si tamen aliquis de filiis receptatorum vel fautorum detexerit aliquem Patarenum, de cuius huiusmodi manifeste probetur perfidia, in fidei praemium quam agnovit, famae pristinae de imperiali clementia restitutionis in integrum beneficium consequatur.

28. T. Ripoll, ed. Bullarium ordinis fratrum praedicatorum 1 (Rome 1729) pp. 125-128. On Frederick's legislation dealing with heresy, see G. de Vergottini, Studi sulla legislazione imperiale di Federico II in Italia: Le leggi del 1220 (Milan, 1952) pp. 1-60; 166-176; 265280. On Frederick's legislation in general, see H. Dilcher, Die sizalische Gesetzgebung Kauser Friedrichs II.: Quellen der Constitutionen von Melfi und ihrer Novellen (Köln, 1975).

29. Bullarium, p. 126. "si ... latentem patrum perfidiam revelaverint ... predicte punitioni non subjaceat innocentia filiorum." See E. Vacandard, The Inquisition (New York, 1908), p. 246.

30. Maisonneuve, L'inquisition, p. 260. In Spain, the legislation of Alfonso the Wise (1255) refused to punish orthodox sons, see $\mathrm{H}$. C. Lea, A History of the Inquisition of the Middle Ages (New York, 1888), 2.183.

31. Constitutionum regni Siciliarum libri III cum commentariis ueterum jurisconsultorum (Naples, 1773), pp. 12-15 contains the commentary of Marinus de Caramanico and Andreas de Isernia. 
[We order that the shelterers, believers, accomplices of the Patarines, and those who support them in any way should be sent into exile forever and should have all of their goods confiscated, for they shortsightedly do not fear for themselves when they protect others from punishment. Their sons should not assume any honors but should suffer the disgrace of perpetual infamy. They should not be admitted as witnesses in cases from which the infamous are barred. However, if one of the sons of the receivers or supporters should expose a Patarine whose perfidy is manifest, his infamy will be entirely removed through the grace of imperial clemency, as a reward for the faith which he acknowledged.]

The decree had three main provisions: 1) the receivers and supporters of heretics should have their goods confiscated; 2) their sons should be disgraced with the legal impediment of infamy; 3 ) their sons should be exonerated and have their good names restored to them if they expose a heretic. These last two sanctions were obviously out of step with contemporary canon law.

There is evidence that Patarenorum receptatores was modified during Frederick's lifetime. When the law was reissued at Ravenna in 1232 and later included in a decretal of Innocent IV in 1243, the section summantur-aliquatenus [Their sons should suffer the disgrace of perpetual infamy. They should not be admitted as witnesses in cases from which the infamous are barred.] was omitted, and the provision which allowed the sons of heretics to redeem themselves was changed significantly to: "Si tamen aliquis fautorum huiusmodi detexerit aliquem Patarenum" [If any of the supporters of heretics should expose a Patarine]. In this version, the supporters of heretics could avoid punishment if they exposed heretics, and their sons were forbidden only from receiving honors. ${ }^{32}$ The punishments for the sons of "shelterers and accomplices" were dropped, except for the provision which prevented them from receiving honors. The change was probably not fortuitous, for the emended text of Patarenorum receptatores is found in the letters of Petrus de Vinea who, some historians think, helped to shape the original Liber Augustalis. The evidence of Patarenorum receptatores might indicate that Peter was not responsible for the original draft of the compilation, but when given the opportunity, his knowledge of law convinced him to bring the decree into greater concord with canon law. Marinus de Caramanico (c. 1285), the ordinary glossator of the Liber Augustalis, objected to the wording of Patarenorum and suggested a similar change in his commentary. ${ }^{33}$

32. Bullarium, pp. 125-128. Monumenta Germaniae Historica, Leges (Hannover, 1896) 2:328-329. Patarenorum was also reissued by Padua in 1238 in its revised form. Also Maisonneuve, L'inquisition, pp. 313-314; 255-256.

33. Petrus de Vinea, Epistolae (Ambergae, 1609), pp. 180-181. Marinus to L.A. 1.2 v. Si tamen aliquis: "Si tamen aliquis de credentibus. Nota rubricam; alias est de credentibus, fautoribus, etc. quae litera bona est; alias de filiis receptatorum vel fautorum, etc. et haec litera non est bona, nam sic supra 1. proxima, de poena filiorum loqueretur in filis receptatorum et fautorum, quod esset summe iniquum, ut ad eorum filios poena transiret" (ed. ctt. 14). Although the lawyers did not accept the penalty which 
In fact, Marinus' commentary to the entire decree shows a skillful blending of ideas which the canonists had already developed, for he used ecclesiastical law to alter the clear intent of Frederick's legislation. Even though Patarenorum receptores undoubtedly deprived the supporters and receivers of heretics of their possessions, Marinus argued that they were only excommunicated - after one year of defiance they were then condemned as heretics and were subjected to the penalty in Patarenorum. For, Marinus said, the penalties (of canon law) were not increased by this constitution, and the sanction of this decree (confiscation) is added (after one year), but nothing is taken away from the earlier decretals. ${ }^{34}$ In the section on the sons of heretics' supporters, he was faced with an equally difficult matter. If he wished to adapt Frederick's legislation to canon law, he had to eliminate the provision or change its meaning. His solution was clever, if a little improbable. He addressed himself to the words ipsorum filii ("their sons") and stated that "ipsorum" did not refer to the "receptatores, credentes, complices et fautores" in the first sentence of the decree (which indeed it does), but to the first word of the law "Patarenorum." With this piece of questionable grammar, Marinus made Frederick's law conform to the canons: according to his reading of the law, only the sons of heretics were considered in Patarenorum $!^{35}$

The question still remained whether the sons of heretics should be disinherited. Marinus observed that according to the ius commune, a son should not be punished for the sins of his father, but the sons of heretics were an exception to this rule because the crime of the fathers was so "monstrous." The lawyers, he said, put forward two reasons for breaking with the ius commune: the stringent penalty would make fathers hesitate to jeopardize their sons, or the sons, being intimate with their fathers, would have known of their fathers' crimes and would be tinged with guilt. In either case, the punishment was appropriate. Quoting Exodus 20:5, Marinus noted that divine eloquence demanded punishment of God's "enemy and the children, to the third and fourth genera-

Patarenorum specified for the sons of supporters and although the law was revised subsequently, the manuscripts of the Liber Augustalis indicate that the law retained its pristine form. See the latest edition by $\mathrm{H}$. Conrad, T. von der Lieck-Buyken and W. Wagner, Die Konstitutionen Friedrichs II. von Hohenstaufen für sein Königreich Sizilien (Köln-Wien, 1973). Also K.-V. Selge, "Die Ketzerpolitik Friedrich II.", Probleme um Friedrich II., ed. J. Fleckenstein (Sigmaringen, 1974), pp. 309-343.

34. Marinus to L.A. 1.2 v. Patarenorum fautores: "Sunt etiam isti tales excommunicati ipso iure, scilicet per sententiam latam a canone, ut extra de haeret. c. Sicut ait et cap. Excommunicamus... et postquam quilibet ipsorum receptatorum, credentium, defensorum, seu quocunque modo fautorum, denuntiatus est, et ex huiusmodi causa excommunicatus sit, satisfacere contempserit infra annum, ex tunc ipso iure infamis efficitur... et tunc etiam credentes haereticorum inter haereticos computantur, et tanquam haeretici judicantur ... nec innovantur predictae poenae per poenam huius constitutionis, immo haec poena nihil praedictis derogans adiicitur" (ed. cit. p. 12).

35. Marinus to L.A. 1.2 v. ipsorum filii: "Scilicet Patarenorum" (ed. cit. p. 13). 
tion." Sons should not be imitators of their fathers. ${ }^{36} \mathrm{He}$ also asked whether fathers could be punished for their sons' heresy, but concluded that fathers were not under anyone's jurisdiction, whereas a son was "tamquam res patris." 37 This distinction was not without purpose, for Marinus then pointed out that only sons not yet emancipated fell under the penalty of the law, and not those sons who had been freed from patria potestas before their fathers' heresy. ${ }^{38}$ If a father did not suffer for his sons's wrongs because he was not tamquam res filii, then an emancipated son was equally immune.

If the first century of commentary on Vergentis and later legislation on heretics produced a wide variety of opinions, the next two hundred years contributed little to the debate. Although the lawyers often referred to the opinions of Tancred and Hostiensis, most of them favored the position of Johannes Teutonicus and Bernardus Parmensis. ${ }^{39}$ By the fifteenth century, legal opinion had hardened. Johannes Andreae (c. 1340) had cited Tancred's and Goffredus' gloss that Vergentis did not prevail outside the papal states, and Panormitanus mistook Johannes' reference as an endorsement of their opinion. Rarely, he grumbled, had Johannes ever had such an improbable opinion. ${ }^{40}$ In fact, though, Johannes merely presented both sides of the question and did not decide the issue. At the end of his gloss he noted that Vergentis and an imperial decree, Gazaros (Authen. post Cod. 1.5.19) were in agreement. ${ }^{41}$ Hence, by implication, Tancred and Goffredus were wrong. Panormitanus was not alone in thinking that Johannes had favored the opinion he cited, although some lawyers read Johannes' text more carefully. ${ }^{42}$

36. Ibid.: "Et ideo tanquam imitatores paterni sceleris puniuntur, juxta illud divinum eloquium: Ego sum Deus zelotes vindicans peccata patrum in filios usque ad tertiam et quartam progeniem in his qui oderunt me."

37. Ibid.: "Et e contrario, pater pro filio haeretico non punitur. Nusquam enim est reperire quod patres ex delicto filii puniantur. ... et est ratio diversitatis huius, quia filius est tanquam res patris, cum pater in eo proprietatis jus habeat."

38. Ibid.: "Ultimo sciendum est quod secundum allegata superius videtur poenam constitutionis huius inflictam filiis locum habere in filio in potestate patris constituto; secus forte in filio emancipato ante paternum errorem, sicut et in filio emancipato ante crimen majestatis excogitatum cavetur, ut C. ad leg. Jul. maj. 1. Quisquis."

39. Besides those lawyers mentioned in the paragraphs which follow, Petrus de Ancharano, Antonius de Butrio, Zabarella, Johannes de Turrecremata, Panormitanus, Johannes Grassus (Prague MS VIII A 5c, fol. 246r), and Marinus Socinus rejected any amelioration of Vergentis' provisions.

40. Panormitanus to X 5.7.10: "Et mirandum de hac opinione Joannis nam raro habet opinionem saltem non probabilem" (Commentara [Lyon, 1522], vol. 2, fol. 41v).

41. Johannes Andreae, Commentara (Venice, 1581), vol. 5, fol. 49r: After citing Tancred, Goffredus and Hostiensis, Johannes concluded: "Sed aucten. Gazaros contradicere uidetur, quae concordat huic iuri canonico et uersiculo huius decretalis (Vergentis)."

42. Antonius de Butrio, Petrus de Ancharano and Marinus Socinus also misinterpreted Johannes' gloss, as does Maisonneuve, L'inquistion, pp. 355-356. The seventeenthcentury lawyer, Prospero Fagnani, Commentaria (Venice 1742) p. 95, noticed that "licet revera Jo. Andr. videatur postea ab ea recessisse, quia paulo post subjungit obstare Auth. Gazaros. C. de haeret. et Manich., quam dixit concordare cum textu nostro." 
The decree to which Panormitanus referred, Gazaros, had an interesting history. It had been taken from the first part of Frederick II's legislation of 1220, and, at the end of the thirteenth century the schools inserted the law into the Code of Justinian. Frederick had also sent his legislation to Bologna, and Tancred placed the same law in Compilatio quinta. But the lawyers did not cite Gazaros as part of the Code until Marinus de Caramanico and Guilielmus Durandus quoted it in the late thirteenth century. ${ }^{43}$ Of the earlier lawyers, Azo, Accursius, Bernardus Parmensis, Hostiensis, and Guido de Baysio did not mention Gazaros, and the lawyers did not refer to the decree regularly until the fourteenth century. The first word, Gazaros, was a corruption of Catharos, the beginning word of Frederick's original legislation. The version of the law which Frederick sent to Bologna may have begun with Gazarenos, which explains how the authentica received its peculiar beginning. ${ }^{44}$ The lawyers of the fourteenth and fifteenth centuries used Gazaros to reject Tancred's and Goffredus' opinions and said that both canonists were wrong because the emperor had issued legislation which supported Vergentis. Cynus of Pistoia (c. 1325) admitted that Gazaros was a harsh law, but added that those who would not accept it were wrong for "durum est contra stimulum calcitrare" (It is futile to fight against the pain, Acts 9:5). Besides, Cynus said, Frederick II's legislation had been approved by the church. ${ }^{45}$

The only lawyer of this period who wanted to limit the responsibility of sons for the sins of their fathers was Johannes Calderinus (c. 1340) who believed that sons who were born before their fathers' crime should be exempt from punishment. Roman law, he said, dictated that a son who had been born before his father had received an honor could not claim that honor through hereditary succession, and, conversely, a son should not be burdened with supervenient punishment. There was a physiological reason as well: sons who were conceived while their fathers were heretics were born sanguine improbato ("with monstrous blood") as part of their nature. ${ }^{46}$

43. The original text is in MGH Leges 2.244. 5 Comp. 5.4.1 (X ---). Marinus to L.A. 1.1,ed. cit. p. 9. Guilielmus' reference is quoted by Maisonneuve, L'inquisition, p. 354.

44. Noted in the apparatus of the edition in MGH Leges 2.244 .

45. Cynus of Pistoia, Commentaria in codicem (Frankfurt A/M, 1578), fol. 23v to Gazaros: "et hanc opinionem tenuit Goff. et Tancred. glossatores iuris canonici, sed eam non patitur ratio ... unde durum est contra stimulum calcitrare." To Cod. 9.8.5, fol. 543v: "Sexto quaeritur iuxta hoc, nunquid sit idem in filiis haereticorum etiam orthodoxis? Roffred. voluit dicere quod non, sed contrarium est veritas, ut supra de haeret. authen. Gazaros, et ibi dixi. . . . Ista sunt verba constitutionis eius [Frederick's, which he has just quoted] quam ecclesia Romana approbauit." I have not had access to Roffredus' work.

46. Johannes Calderinus, Consilia (Venice, 1582), fol. 93v-94r: "In contrarium facit 1. Emancipata, ff. de sena. cum materia sua. Item facit, quia filius ante natus ex supervenienti dignitate in persona patris non consequitur priuilegium uel honorem ... ergo nec poenam uel onus.... Et hic intellectus est magis fauorabilis et 
But Calderinus', Tancred's, Goffredus', Hostiensis' and Marinus' opinions were not commonly accepted. At the end of the fifteenth century Felinus Sandaeus allowed only four exceptions to Vergentis: in the case of converted Jews who relapsed, their sons would not be punished; sons who were descended from the maternal side (as established by a decretal in the Sext of Pope Boniface VIII $6-5.2 .15$, Statutum); if a heretic was reconciled to the church before he died; and finally if a heretic died undiscovered, and his son held his inheritance for forty years, the son then held possession of the property through prescription. ${ }^{47}$ This last exception was new and came to be generally accepted by the later lawyers.

The sixteenth century witnessed both an increase in cases of heresy and a concomitant renewal of interest in the legal aspects of heresy. Alfonso de Castro wrote a famous and fiercely polemical tract about heresy - a book whose style betrays the practitioner's mentality and a sensitivity to public opinion-and he lamented the folly of those who questioned the persecution of heretics. During the years in which he labored to root out heresy in Flanders, most men admitted that heretics must be punished, but inveighed against him for the cruelty of punishing the innocent children of heretics. They agreed that the heretics themselves should be punished, but, quoting Ezechiel 18:20 ("The son shall not suffer for the iniquity of the father."), they were appalled that the orthodox sons of heretics would be punished for the sins of their fathers. Alfonso responded that the reasons for not punishing the orthodox sons of heretics seemed as indissoluble as the knot of Hercules. ${ }^{48}$ Nevertheless, he then wrote a trenchant defense of current practices in inquisitorial courts. Alfonso was not a lawyer and did not always recog-

consonat aequitati, maxime ubi de admittendo filium orthodoxum ante natum ad officia et honores agitur ... et potest etiam ratio diuersitatis quia qui nascuntur postea, nascuntur sanguine improbato, quod in filiis ante natis non est."

47. Felinus Sandaeus, Commentaria (Lyon, 1547), fol. 243v-244r, to X 5.7.10: "Sed fallit primo, nisi esset iudaeus conuersus, quia si demum relabitur hoc non nocet filiis. . . Fallit secundo in filiis et aliis descendentibus ex linea materna.... Fallit tertia nisi haereticus ante mortem reconcilietur, ut ibidem. Quarto, nisi filii post mortem patris haeretici qui putabatur christianus, tenuissent per xl. annos bona."

48. Alfonso de Castro, De iusta haereticorum punitione (Salamanca, 1547), p. 322. "Vidi enim ego multos in Flandria, cum illic ante annos decem versarer, qui licet iustum esse censebant haereticos puniri, male tamen illos habebat parentum haereticorum poenas ad filios eorum esse protensas.... Dicebant enim indignum esse, ut quis sine culpa puniatur [and for support they quote Augustine and Ezechiel]." The canonists had noticed the contradiction between the two biblical texts almost immediately, but they were not bothered by the conflict. Innocent III discussed both texts when he dealt with the postulation of illegitimate clerics in Innotuit [3 Comp. 1.6.5 (X 1.6.20)]. While glossing Innotuit (v. non est filiis imputanda) Vincentius Hispanus observed that sons were freed only from guilt, but not from punishment, "quo ad culpam < non $>$ inputatur, tamen quo ad penam, infra de hereticis Vergentis. vi. q.i. § Verum" (St. Gall 697, fol. 20v), and perhaps his solution satisfied the canonists. Marinus de Caramanico was the only early lawyer who cited both biblical texts in his commentary (supra n. 36). 
nize the logical implications of his position. In another section of his treatise, he asked to whom a kingdom should devolve if the king became a heretic? His tentative answer was to the eldest son, but he modestly deferred to the lawyers for a definitive solution. ${ }^{49}$ At least one lawyer, Diego de Simancas, following the rigorous logic of the law, thought that the son should not inherit his father's kingdom. ${ }^{\mathbf{5 0}}$

Very few of the lawyers questioned the right of either the church or the state to punish the sons of heretics during the religious turbulence of the Reformation. They were convinced that Ezechiel 18:20 meant that God would never punish the innocent with eternal punishment, but, for them, Exodus 20:5 established the right of the human legislator to punish the innocent in this world. Although there was one case in which humanist lawyers argued against the confiscation of goods, it was exceptional. Both Guillaume Budé and Johannes Igneus examined a decree of 397 in which the Emperors Honorius and Arcadius stipulated that the sons of traitors to the emperor should be disinherited (Cod. 9.8.5, Quisquis). Two years later, they noticed, the same emperors issued another decree (Cod. 9.47.22, Sancimus) which stated that "peccata igitur suos tenant auctores," but which had nothing to do with traitors. This second, later law, they argued, vitiated the provisions of the earlier one; therefore sons could not be disinherited for the crime of their fathers. ${ }^{51}$ It was clever reasoning, but bad law. Lawyers pointed out that a decree could never be annulled by a general mandate, unless the law was mentioned explicitly; Budé's argument attracted no support. Ambrosius de Vignate was the only canonist who thought that the sons of heretics should inherit their share of their fathers' patrimony. He cited the reasons of Tancred, Goffredus, and Azo, but his opinion was unusual. ${ }^{52}$

The earlier arguments which did attract attention in the sixteenth and seventeenth centuries were Calderinus' and Tancred's. Tancred's, however, was not given a serious hearing, and the lawyers marveled that Johannes Andreae had been seduced by such sophistry. Unlike most lawyers, Prospero Fagnani, who understood Johannes' gloss, knew that

49. Ibid., pp. 301-302.

50. Diego de Simancas, De catholicis institutionibus: Liber ad praecavendas et extirpandas haereses (Ferrariae, 1692), p. 63. "Sed propter heresim regis, non solum rex regno privatur, sed et eius filii a regni successione pelluntur, ut noster Lupus loculenter probat, ergo primogenita pari ratione confiscari possunt."

51. G. Budé, Annotationes in pandectas (Opera omnia, vol. 3; Basel, 1552), p. 308. "Qua lege [Sancimus] ego legem Quisquis abrogatam esse aliquando censui ... proprius mihi videtur, antiquiorem legem posteriore abrogari." Budé was not, however, discussing heresy in this passage. I have not had access to Johannes Igneus' work, but I know of his opinion from Simancas' reference to it.

52. Ambrosius de Vignate, De heresi [Tractatus universi iuris, vol. 11, pt. $2=$ TUI (Venice, 1584)], fol. 17r. "Ergo aequa est lex civilis faciens pro Azone et sequacibus, ut filii haereticorum non puniantur. Et ideo dato quod d. c. Vergentis contradiceret ad litteram, equitas legum preallegatarum videtur preferenda." 
Johannes recognized that there could be no difference between those lands subjected to the emperor and those owing allegiance to the church. ${ }^{53}$ Calderinus' argument was more attractive and convinced a small number of lawyers, but a typical reaction was that of Antonius Ricciulus. He thought the sons who were born before their fathers' heresy would be adults when their fathers were condemned, and their poverty and disgrace would be greater punishment for the heretic than that of an infant. ${ }^{54}$

However, these questions were merely peripheral in the sixteenth and seventeenth centuries, for the lawyers had established a firm consensus which adhered to the strict rigor of the law. The problem which the lawyers confronted with regularity was moral rather than legal. The inquisition had been functioning for several centuries, and the inquisitors who meted out sentences must have faced, again and again, the brutal reality of condemning innocent children to a life of poverty. For some, the problem was not serious. Paolo Grillardo bristled when he faced the argument that the orthodox sons of heretics should receive at least a portion of what was due them by natural law. On the contrary, they should not inherit one denarius, he wrote, but should suffer always and be ever in dire need: life should be pain and death solace. ${ }^{55}$ Diego de Simancas concurred and turned the maxim of Roman law on its head, saying: "horum benignius affectus laudandus quidem est, expedit tamen Reipublicae, ut filii quoque haereticorum egestate laborent" (cf. Dig. 16.3.31). ${ }^{56}$

Other lawyers thought that inquisitors should provide for the innocent children of heretics and not leave them entirely destitute. In Spain, the custom had been established that inquisitors should care for the children of heretics not out of any legal duty, but from mercy. Francisco Peña wrote in his commentary to Nicholas Eymeric's Directorium inquisitorum that inquisitors should provide for small children by appointing honest matrons of the city to raise and instruct them in the faith. Older children, who were either too young or too weak to work, should be given a small amount from their fathers' possessions so they

53. Commentaria, p. 93. "Atque ita Jo. Andr. agnovit hanc differentiam constitui non posse inter loca imperio vel ecclesiae subjecta."

54. Antonius Ricciulus, Tractatus de iure personarum extra ecclesiae gremium existentium (Rome, 1622), p. 474. "Ergo multo magis debent habere locum in natis ante delictum, quam in aliis cum maior sit afflictio videre filium adultum, saepe etiam bonis ditatum, et in dignitate constitutum gradu deiici, quam filios infantes."

55. Paolo Grillando, De hereticis, TUI, fol. 25v. "Sed in contrarium est veritas, quia ipsi filii effecti sunt a iure adeo inhabiles et incapaces paterne successionis, quod illi etiam in uno denario succedere non possunt, imo debent semper in miseria et egestate sordescere, sicut filii reorum criminis laesae maiestatis, adeo quod nihil aliud eis relinquendum est nisi sola vita, que ex misericordia elargitur. Et tales esse debent in hoc mundo, quibus vita supplicium et mors solatium."

56. De catholicis institutionibus, p. 31 . 
might live. Peña said that the inquisitors should urge those princes who confiscated the property of the condemned to exercise liberality with the children. ${ }^{57}$ Some lawyers tried to establish the legal right for such aid, but the communis opinio upheld the principle that the children had no right, but received help only ex misericordia. ${ }^{58}$ By the seventeenth century, common practice dictated that sons and daughters who had not reached the age of puberty be given sustenance, but that daughters should also receive a dowry. Antonius Ricciullus thought that this distinction was equitable because of the imbecility of females; they needed more protection than males because of the weakness of their sex. The dowry, however, should not be large. ${ }^{59}$

At this late date, the inquisition had already become a hollow vessel which no longer exercised its former terror in Christendom. The lawyers still involved themselves with the legal problems which this "peculiar institution" of the Middle Ages created, and the literature on heresy which was written in the late sixteenth and early seventeenth centuries is copious. But as we have seen, the lawyers of the later period approached the inquisition and its laws quite differently from their predecessors. While the early lawyers felt that they could subvert the repugnant provisions of the law through reason, using cleverly constructed parallel arguments from Roman and canon law to undermine the intent of Vergentis, in the late medieval and early modern world, lawyers were not so willing to compromise the intent of the legislator. They could only recall Hostiensis' suggestion that the punishments for heresy could be ameliorated ex misericordia, applying the balm of mercy to the unrelenting rigor of the law.

57. Directorium inquisitorum (Venice, 1595), p. 99. "Inquisitores tamen pueris et puellis haereticorum damnatorum pauperibus relictis providebunt ex misericordia, ita ut rationem habeant sexus et aetatis, nam masculos iam corpore validos alicui arti mechanicae iubebunt addici; foeminas, aliquibus honestis eiusdem civitatis matronis assignabunt ut eis famulentur et ab eis in fide instruantur. Caeteris, quibus per aetatem aut incommodam valetudinem laborare non licet, tenuia alimenta ex paternis bonis ex sola misericordia subministrabunt, deprecantes interdum principes, tam ecclesiasticos quam saeculares, ut huiusmodi filios damnatorum, aliquam exerceant liberalitatem, quae res ad eos in primis spectat ad quos damnatorum bona ex confiscatione pervenerunt." On Peña, see E. Peters, "Editing Inquisitors' Manuals in the Sixteenth Century: Francisco Peña and the Directorium inquisitorum of Nicholas Eymeric," The Library Chronicle of the University of Pennsylvania, 40 (1974): 95-107. Peña discusses aspects of the problem on pp. 659-671.

58. Antonius Diana Panormitanus, Omnes resolutiones morales (Lyon, 1568), vol. 5, p. 459, stated that five lawyers thought that the orthodox sons of heretics had a legal right to aid. However, he concurred with Peña that they had no right, but agreed that they could be ministered to ex misericordia.

59. Tractatus de iure personarum, p. 509. "Nec mirum quod aequitas restringatur ad dotes filiarum et alimenta filiorum impuberum, quia habita est ratio imbecellitatis sexus et etatis... Quantitas autem dotis in hac specie non potest praetendi pro naturalium dignitate, sed simpliciter mediocrem." They did not, however, have a right to a dowry or support. 
Another aspect of this contrast between the earlier and later lawyers is shown by Emanuel Gonzalez Tellez' commentary to Vergentis in the early seventeenth century. He carefully compared the text which he found in the Gregoriana with the extended version in Compilatio tertia and noticed that Raymond de Pennafort had made several significant alterations of the decretal. The most important change was that Vergentis no longer applied to heretics and to their supporters equally. Tellez understood that Innocent III had applied the Roman law of treason to heresy and outlined how the punishment of treason differed from that of heresy. ${ }^{60} \mathrm{He}$ then reviewed the legal literature in which the lawyers had analyzed the problems created by the confiscation of goods and decided that the justice of the law governing heresy could only be explained in a historical perspective. There were, he said, three different ages in which Christians persecuted heretics. When the church was first born, just as a new seedling has only tender shoots, the church could not fight heresy vigorously. But later, in the time of Arcadius and Theodosius, the goods of heretics were confiscated only if they did not have orthodox sons or relatives because these imperial measures encouraged children to denounce or correct their parents. In the third age, "our Innocent" decreed that the goods of heretics should be confiscated completely, and Innocent's legislation had been confirmed by later popes. ${ }^{61}$ In the case of heresy, the unraveling of history justified the increasing rigor of the law. Tancred and Goffredus had not been blind to historical perspective; they only assumed that new law was not always better, or in this case, more equitable, than old law. History, however, did not free Tellez entirely from the logic of earlier arguments. At the very end of his commentary, he wrote that perhaps the sons who had been born before their fathers' crime were exempted from punishment-but he did not endorse Calderinus' old opinion. ${ }^{62}$ Some remnants of medieval legal logic still ruled, if weakly, even from the grave.

60. Commentaria, 2.179. See n. 7 .

61. Ibid., p. 184. "Successit tertium tempus nostri Innocentii qui presenti textu absolute constituit bona haereticorum esse confiscanda per sententiam, quamtumvis filios habeant catholicos."

62. Ibid. "Ad filios tamen ante delictum genitos non protrahi praesentem textum [Vergentis] docuerunt plures, quos refert et sequitur Marinis, tom. 2 resol. cap. 95." Tellez, p. 180, listed three seventeenth-century lawyers who denied that orthodox sons should be punished, but I have not had access to their works. 